\title{
FIELD PERFORMANCES OF SOME LOCAL POTATO CULTIVARS FROM EASTERN TURKEY IN THE AEGEAN REGION
}

\author{
Zihin YILDIRIM*, Gulsum OZTURK \\ Ege University, Faculty of Agriculture, Department of Field Crops, Izmır, TURKEY \\ *Corresponding author: zihin.yildirim@ege.edu.tr
}

Received: 25.01.2016

\begin{abstract}
Nine local potato cultivars from Eastern Anatolia selected in the seedbed growing stage were tested for agronomical performance in a field trial arranged in the Randomized Complete Block Design with 3 replications at Bornova in 2014 and 2015. Based on the multiple comparisons, local potato cultivar Posof had the highest means for plant height $(60.5 \mathrm{~cm})$, stem number $(4.9)$, leaf number $(89.9)$, leaf width $(2.4 \mathrm{~cm})$, tuber number (11.2), plant yield $(762.7 \mathrm{~g})$ and plot yield $(3.8 \mathrm{~kg})$. Local varieties Pasha $(4.2 \mathrm{~cm}), \mathrm{BCB}(4.2 \mathrm{~cm})$ and Pashaplateau $(4.2 \mathrm{~cm})$ over passed Posof for only leaf length. Local cultivar ABK had the highest means for single tuber weight $(81.6 \mathrm{~g})$, tuber length $(6.4 \mathrm{~cm})$ and tuber width $(4.8 \mathrm{~cm})$. Local varieties $\mathrm{PC}(10.8)$ and Pasha (9.9) had high means for number of tubers. Also Pasha (589.4 g), Bayburt (522.7 g) and ABK (563.8 g) had high plant yield. It could be concluded that Posof had superior performance in the Aegean Region as compared to the remaining. Posof, Pasha, BCB, Pasha-plateau, ABK and Bayburt could be further tested in the regional variety testing trial as well as to be used as parents in the breeding programs for the Aegean Region.
\end{abstract}

Keywords: Land race, local potatoes, morphological traits, yield traits

\section{INTRODUCTION}

Potatoes were introduced to Turkey during the $19^{\text {th }}$ century from France through the Balkans and from Germany over Russia through Caucasia into eastern Black Sea and eastern Anatolia. Potatoes were first grown in the Sakarya basin in 1876 (Gunel, 2002). High demand for potatoes in Istanbul resulted in import of potatoes so potato production has been started in the Sakarya river area close to Istanbul (Oguz, 1976; Savkay, 1999). Later a potato research station was established in this area headed by a German researcher Dr. Herman (Oguz, 1976). In the western Turkey potato production was limited and depended on seed tubers so seed potatoes were imported from France as early as in 1910 (Gunel 2002). Only one potato cultivar released by the Sakarya Research Station known as 'Sarıkı'-'blond girl' with high cooking quality has been widely accepted.

On the other hand, potatoes introduced to the eastern Turkey from Russia were grown in the various plateaus of Black Sea and the eastern Anatolia. They were preserved by the inhabitants in those separated niches. Kara (2002) reported that seed potatoes had been produced in Pasinler Erzurum as early as in 1881 . The potato populations grown in the highlands have still been grown commercially. These landraces are called local varieties with considerably variation for the characteristics to be used in selection programs. Several studies have been conducted in the
Region by collecting and testing those genetic materials for their desirable quality and yield characteristics as well as their resistance against the environmental stress conditions (Aslan et al., 2004; Arslanoglu 2008; Kara, 2002; Karaca and Aytac, 2006; Karadogan and Gunel, 1992; Yilmaz and Karan, 2007). Recently one specific local population named 'Basciftlik Beyazı'-(Head Farm's White) was released in the Tokat province by the University of Gaziosmanpasha (Yilmaz and Karan, 2007).

There has been limited investigation on the local potato cultivars of the eastern Turkey. Karaca and Aytac (2006) have investigated the agronomical and technological characteristics of the 63 potato clones collected in the Ordu province of Black Sea Region. They have reported significant differences among the potato clones for yield, quality and storage characteristics. Local potatoes grown in Artvin province in the eastern Black Sea were studied and large variations for yield were found and their importance in potato breeding was discussed (Arslanoglu, 2008). The genetic relationships of the local potato cultivars grown in the eastern Turkey were studied by Akkale et al. (2010) and they reported a wide genetic variation among the local cultivars.

In the region, growing potatoes from old seed tubers for several years has resulted in yield reduction due to biotic stress. Therefore land race potato populations obtained from eastern Anatolia were cleaned from viruses through 
meristem culture and then they were tested in seed beds in the Department of Field Crops of the Aegean University. Alabalik village population was found to be superior for yield and tuber characteristics (Aydemir, 2014).

The purpose of this study was to evaluate field performances of some local potato clones originated from the Black Sea and the eastern Anatolia under the field conditions of the Aegean Region.

\section{MATERIALS AND METHODS}

The local potato populations obtained from the eastern Anatolia were cleaned up by using meristem culture in the laboratory and then they were multiplied through micro propagation. First they were grown in the seedbeds to test their tuber yield (Aydemir et al., 2013).

The local cultivars selected in the seedbed growing stage were advanced to the agronomical performance stage in a field trial conducted at Bornova during 2014 and 2015.
Information pertinent to the land race potato genotypes are given in Table 1.

The design of the field trial was a Randomized Complete Blocks with 3 replications. The field experiment was arranged in single row plots 1.5 meter in length including 5 hills. The spacing was $70 \mathrm{~cm}$ and $30 \mathrm{~cm}$ among the rows and within the rows respectively. The field trial was planted by hand on 13 February in 2014 and on 20 February in 2015.

During the vegetation period standard procedures were applied and irrigated as required. The field trial was harvested on 14 July in 2014 and on 2 July in 2015.

Plant characteristics such as plant height $(\mathrm{cm})$, stem number, leaf number, leaf length $(\mathrm{cm})$ and width $(\mathrm{cm})$ were measured during the growing period and agronomical traits such as, tuber number, plant yield (g), single tuber weight $(\mathrm{g})$, plot yield $(\mathrm{kg})$, tuber length $(\mathrm{cm})$ and tuber width $(\mathrm{cm})$ were measured at the harvest and following the harvest.

Table 1. Local potato populations tested in the field trial at Bornova in 2014 and 2015

\begin{tabular}{|c|c|c|c|}
\hline Code name & Local name & Province & Source \\
\hline Posof & Posof & Erzurum & Eastern Anatolian Agricultural Research Institute-Erzurum \\
\hline Bayburt & Bayburt & Bayburt & Bayburt province \\
\hline Pasha & Pasha & Akcaabat-Trabzon & $\begin{array}{l}\text { Akcaabat District Directorate of the Ministery of Food } \\
\text { Agriculture and Livestock }\end{array}$ \\
\hline $\begin{array}{l}\text { Pasha- } \\
\text { plateau }\end{array}$ & Pasha-plateau & Akcaabat -Trabzon & $\begin{array}{l}\text { Akcaabat District Directorate of the Ministery of Food } \\
\text { Agriculture and Livestock }\end{array}$ \\
\hline $\mathrm{PC}$ & Posof central & Erzurum & Eastern Anatolian Agricultural Research Institute-Erzurum \\
\hline $\mathrm{ABK}$ & Alabalik village & Ardahan & Eastern Anatolian Agricultural Research Institute-Erzurum \\
\hline PDK & $\begin{array}{l}\text { Posof dogrular } \\
\text { village }\end{array}$ & Erzurum & Eastern Anatolian Agricultural Research Institute-Erzurum \\
\hline $\mathrm{BCB}$ & $\begin{array}{l}\text { Basciftlik beyazi } \\
\text { (Head Farm's White) }\end{array}$ & Tokat & Potato Research Station-Nigde \\
\hline PCYK & $\begin{array}{l}\text { Posof Camyazı } \\
\text { village }\end{array}$ & Erzurum & Eastern Anatolian Agricultural Research Institute-Erzurum \\
\hline
\end{tabular}

\section{Statistical Analyses}

The standard analysis of variance techniques were used in the statistical analysis of the data (Ac1kgoz et al., 2004). The means of the local cultivars were compared by using the LSD test as described by Steel and Torrie (1980).

\section{RESULTS AND DISCUSSION}

The variance sources and their statistical significance were shown in table 2 and table 3 for the morphological and the agronomical characteristics respectively.

It could be seen in table 2 that the genotype, year and genotype $\mathrm{x}$ year interaction sources of variation were significant at the $\mathrm{p} \leq 0.01$ level of probability for all morphological traits studied. Same trend was also observed in the table 3 for the agronomical characteristics of the local potato cultivars.

The highly significant $F$ values of the variance components indicated considerably variation among the genotypes, years and the genotype $\mathrm{x}$ year interaction component of variation.
The significant variance components could be interpreted as a possible selection opportunity among the local cultivars. The significant genotype $\mathrm{x}$ year interaction indicated a selection program based on the means of at least two years (Yildirim and Dere, 2005). Therefore the comparisons of the genotypes were done by using their means over 2014 and 2015 to minimize the genotype $x$ year interaction effect.

The means over 2014 and 2015 of the morphological traits of local potato cultivars were given in table 4 . It could be observed in table 4 that the local cultivar Posof had the highest significant means for plant height $(60.5 \mathrm{~cm})$, stem number (4.9), leaf number (89.9) and leaf width $(2.4 \mathrm{~cm})$; local cultivar Pasha $(4.2 \mathrm{~cm})$, Basciftlik Beyazi (Headfarm White) $(4.2 \mathrm{~cm})$ and Pasha-plateau $(4.2 \mathrm{~cm})$ over passed Posof local cultivar for only leaf length. Besides, Posof had high leaf length $(4.1 \mathrm{~cm})$ following these local cultivars.

Considering the high means of Posof local cultivars it could be concluded that this genotype had superiority over remaining local genotypes for the morphological traits 
studied. Following the morphological traits we could also

expect a high performance from this local cultivar for the agronomical traits.

Table 2. Sources of variation and their significance for the morphological characteristics based on the combined analysis over 2014 and 2015 at Bornova

\begin{tabular}{|c|c|c|c|c|c|}
\hline Source of variation & $\begin{array}{l}\text { Plant height } \\
\text { (cm) }\end{array}$ & $\begin{array}{l}\text { Stem } \\
\text { number }\end{array}$ & $\begin{array}{l}\text { Leaf } \\
\text { number }\end{array}$ & $\begin{array}{l}\text { Leaf length } \\
(\mathrm{cm})\end{array}$ & $\begin{array}{l}\text { Leaf width } \\
(\mathrm{cm})\end{array}$ \\
\hline Genotype & $333.24^{* *}$ & $5.334^{* *}$ & $1046.2^{* *}$ & $2.664^{* *}$ & $0.631^{* *}$ \\
\hline Year & $1041.9^{* *}$ & $264.4^{* *}$ & $7187.6^{* *}$ & $0.463^{* *}$ & $0.098^{* *}$ \\
\hline Genotype x year & $394.52^{* *}$ & $5.251^{* *}$ & $587.35^{* *}$ & $0.320^{* *}$ & $0.273^{* *}$ \\
\hline Error & 24.512 & 0.077 & 12.182 & 0.003 & 0.004 \\
\hline $\begin{array}{l}\text { Coefficient of variation }(\%) \\
(\mathrm{CV})\end{array}$ & 10.14 & 8.42 & 5.06 & 1.61 & 3.01 \\
\hline
\end{tabular}

**: significant at the $\mathrm{p} \leq 0.01$ level

$*$ : significant at the $\mathrm{p} \leq 0.05$ level

ns: non-significant

Table 3. Sources of variation and their significance for the agronomical characteristics based on the combined analysis over 2014 and 2015 at Bornova

\begin{tabular}{lllllll}
\hline Source of variation & $\begin{array}{l}\text { Tuber } \\
\text { number }\end{array}$ & $\begin{array}{l}\text { Plant yield } \\
(\mathbf{g})\end{array}$ & $\begin{array}{l}\text { Single tuber } \\
\text { weight }(\mathbf{g})\end{array}$ & $\begin{array}{l}\text { Plot yield } \\
(\mathbf{k g})\end{array}$ & $\begin{array}{l}\text { Tuber } \\
\text { length }(\mathbf{c m})\end{array}$ & $\begin{array}{l}\text { Tuber } \\
\text { width }(\mathbf{c m})\end{array}$ \\
\hline Genotype & $29.175^{* *}$ & $205132.3^{* *}$ & $1571.8^{* *}$ & $5.968^{* *}$ & $240.37^{* *}$ & $1.313^{* *}$ \\
Year & $444.91^{* *}$ & $977438.5^{* *}$ & $408.93^{* *}$ & $58.89^{* *}$ & $11.840^{* *}$ & $0.602^{* *}$ \\
Genotype x year & $17.709^{* *}$ & $47848.25^{* *}$ & $241.39^{* *}$ & $2.106^{* *}$ & $50.599^{* *}$ & $0.164^{* *}$ \\
Error & 0.305 & 3656.619 & 60.327 & 0.053 & 0.009 & 0.006 \\
$\begin{array}{l}\text { Coefficient of } \\
\text { variation }(\%)(\mathrm{CV})\end{array}$ & 6.65 & 13.46 & 14.36 & 9.66 & 1.78 & 1.88 \\
$\begin{array}{l}* * \\
\text { : significant at the } \mathrm{p} \leq 0.01 \text { level }\end{array}$ \\
$\begin{array}{l}* \text { : significant at the } \leq 0.05 \text { level } \\
\text { ns: non-significant }\end{array}$
\end{tabular}

Table 4. Means of the morphological traits of local potato cultivars over 2014 and 2015 grown in the field trial run at Bornova

\begin{tabular}{|c|c|c|c|c|c|}
\hline Landrace & Plant height $(\mathrm{cm})$ & Stem number & Leaf number & Leaf length $(\mathrm{cm})$ & Leaf width $(\mathrm{cm})$ \\
\hline Posof & 60.5a & $\underline{4.9 \mathrm{a}}$ & 89.9a & $4.1 \mathrm{~b}$ & $2.4 \mathrm{a}$ \\
\hline $\mathrm{ABK}$ & $\overline{58.1 \mathrm{ab}}$ & $3.1 \mathrm{~cd}$ & $68.7 b$ & $3.5 \mathrm{~d}$ & $2.2 \mathrm{bc}$ \\
\hline Pasha & $53.6 \mathrm{bc}$ & $3.3 \mathrm{c}$ & 92.3a & $\underline{4.2 \mathrm{a}}$ & $\underline{2.2 \mathrm{~b}}$ \\
\hline BCB - HFW & $45.3 \mathrm{de}$ & $3.9 \mathrm{~b}$ & $\overline{66.6 b c}$ & $\overline{4.2 \mathrm{a}}$ & $\overline{2.4 a}$ \\
\hline Bayburt & $49.0 \mathrm{~cd}$ & $3.3 \mathrm{c}$ & $67.3 b$ & $\overline{3.2 \mathrm{e}}$ & $\overline{2.2 b c}$ \\
\hline Pasha-plateau & 47.4de & $3.8 \mathrm{~b}$ & $62.8 \mathrm{~cd}$ & $\underline{4.2 \mathrm{a}}$ & $\underline{2.2 b}$ \\
\hline $\mathrm{PC}$ & $43.5 \mathrm{e}$ & $2.9 \mathrm{~d}$ & $58.9 \mathrm{de}$ & $2.7 \mathrm{f}$ & $1.8 \mathrm{~d}$ \\
\hline PCYK & $37.0 \mathrm{f}$ & $3.0 \mathrm{~cd}$ & $57.7 \mathrm{e}$ & $2.5 \mathrm{c}$ & $1.4 \mathrm{e}$ \\
\hline PDK & $44.7 \mathrm{de}$ & $1.4 \mathrm{e}$ & $57.2 \mathrm{e}$ & $3.6 \mathrm{c}$ & $2.1 \mathrm{c}$ \\
\hline $\operatorname{LSD}\left({ }_{0.05)}\right.$ & 5.808 & 0.325 & 4.095 & 0.067 & 0.074 \\
\hline
\end{tabular}

Table 5. Means of the agronomical traits of local potato cultivars over 2014 and 2015 grown in the field trial grown at Bornova

\begin{tabular}{lllllll}
\hline Landrace & $\begin{array}{l}\text { Tuber } \\
\text { number }\end{array}$ & $\begin{array}{l}\text { Plant yield } \\
(\mathbf{g})\end{array}$ & $\begin{array}{l}\text { Single tuber } \\
\text { weight }(\mathbf{g})\end{array}$ & $\begin{array}{l}\text { Plot yield } \\
(\mathbf{k g})\end{array}$ & $\begin{array}{l}\text { Tuber length } \\
(\mathbf{c m})\end{array}$ & $\begin{array}{l}\text { Tuber width } \\
(\mathbf{c m})\end{array}$ \\
\hline Posof & $\underline{\mathbf{1 1 . 2 a}}$ & $\underline{\mathbf{7 6 2 . 7 a}}$ & $\underline{\mathbf{6 8 . 5 b}}$ & $\underline{\mathbf{3 . 8 a}}$ & $5.6 \mathrm{bc}$ & $4.5 \mathrm{~b}$ \\
PC & $\underline{\mathbf{1 0 . 8 a}}$ & $418.3 \mathrm{c}$ & $41.7 \mathrm{f}$ & $2.2 \mathrm{e}$ & $5.2 \mathrm{e}$ & $4.3 \mathrm{c}$ \\
Pasha & $9.9 \mathrm{~b}$ & $589.4 \mathrm{~b}$ & $64.8 \mathrm{bc}$ & $3.0 \mathrm{c}$ & $5.7 \mathrm{~b}$ & $\underline{\mathbf{4 . 8 a}}$ \\
Bayburt & $9.5 \mathrm{~b}$ & $522.7 \mathrm{~b}$ & $59.2 \mathrm{~cd}$ & $2.6 \mathrm{~d}$ & $5.6 \mathrm{c}$ & $\underline{\mathbf{4 . 8 a}}$ \\
BCB - HFW & $7.6 \mathrm{c}$ & $347.6 \mathrm{~cd}$ & $47.9 \mathrm{ef}$ & $1.6 \mathrm{f}$ & $4.9 \mathrm{f}$ & $4.1 \mathrm{~d}$ \\
Pasha-plateau & $7.4 \mathrm{~cd}$ & $396.2 \mathrm{c}$ & $53.1 \mathrm{de}$ & $2.3 \mathrm{e}$ & $5.4 \mathrm{~d}$ & $3.9 \mathrm{e}$ \\
PDK & $7.4 \mathrm{~cd}$ & $318.1 \mathrm{~d}$ & $41.7 \mathrm{f}$ & $1.8 \mathrm{f}$ & $4.9 \mathrm{f}$ & $\underline{\mathbf{4 . 8 a}}$ \\
ABK & $6.8 \mathrm{~d}$ & $563.8 \mathrm{~b}$ & $\underline{\mathbf{8 1 . 6 a}}$ & $\underline{\mathbf{3 . 5 b}}$ & $\underline{\mathbf{6 . 4 a}}$ & $\mathbf{3 . 5 \mathrm { g }}$ \\
PCYK & $4.3 \mathrm{e}$ & $124.0 \mathrm{e}$ & $28.7 \mathrm{~g}$ & $0.6 \mathrm{~g}$ & 0.94 \\
LSD $(0.05)$ & 0.648 & 70.9 & 9.1 & 0.269 & 0.111 & 0.94 \\
\hline
\end{tabular}

This expectation was found to be correct by examining the agronomical traits given in table 5. Local variety Posof had highest means for tuber number (11.2), plant yield $(762.7 \mathrm{~g})$ and plot yield $(3.8 \mathrm{~kg})$ as expected. In addition 
Posof also had high means for single tuber weight $(68.5 \mathrm{~g})$ and tuber width $(4.5 \mathrm{~cm})$.

The local cultivar ABK had the highest means for single tuber weight $(81.6 \mathrm{~g})$, tuber length $(6.4 \mathrm{~cm})$ and tuber width $(4.8 \mathrm{~cm})$ and high mean for plot yield $(3.5 \mathrm{~kg})$. Also local varieties PC (10.8) and Pasha (9.9) had high number of tubers. Local cultivars Pasha (589.4 g), Bayburt (522.7 g) and $\mathrm{ABK}$ (563.8 g) had high plant yields.

Large variations found for the morphological and agronomical traits were in agreement with the earlier reports (Karaca and Aytac, 2006; Kara, 2002; Arslanoglu, 2008; Aydemir et al., 2013). A wide genetic distribution of the landraces was also stressed by Akkale et al. (2010). Early studies on the potato landraces were conducted in the growing areas so their result reflects their real capacities. Yilmaz and Karan (2007) studied the yielding capacity of one local cultivar called Bashciftlik Beyazi - Head Farm's White grown in 'Bashciftlik' district of Tokat province Turkey. They have recommended this local to be released for its high yielding capacity in the region. Bashciftlik Beyazi (Head Farm's White) was also recommended to be used in the potato breeding programs. Various clones of Posof local variety tested in this study expressed wide variation for the agronomical characteristics and one local variety $\mathrm{ABK}$ from Ardahan had some highest means for the traits studied.

In conclusion; based on the comparison of the means of morphological and agronomical traits, local cultivar Posof appeared to have higher means for morphological and agronomical traits and to be superior to the other local cultivars grown in the trial. Local cultivar Posof, could be accepted as a potential genotype to be tested in the regional potato yield trial due to its close performance to the released variety Nif for the agronomical traits such as plant height, stem number, number of leaves, tuber number and plant yield. The landraces tested in this study were all from the highlands of the eastern Turkey so their agronomical performances could be low in the Aegean Region. Therefore the selected landrace clones should be grown in the advanced yield trial in the region before making a solid decision.

\section{LITERATURE CITED}

Acikgoz, N., E. Ilker, A. Gokcol, 2004. Evaluation of biological research on the computer. E.U TOTEM No: 2. Izmir (in Turkish).

Akkale, C., Z. Yildirim, M.B. Yildirim, C. Kaya, G. Ozturk and B. Tanyolac. 2010. Assesing genetic diversity of some potato (Solanum tuberosum L.) genotypes grown in Turkey using the AFLP marker technique. Turk J Field Crops. 15(1): 73-78.

Arslanoglu, F. 2008. Three agronomical traits of the local potato (Solanum tuberosum L.) ecotypes grown in the farmer fields in highlands of the Eastern Black Sea Region. Turk J Field. Crops. 13: 70-76.

Aydemir, T. 2014. Studies on the Physiological, Morphological and Agronomical characteristics in certain local potato (Solanum tuberosum L.) cultivars developed in vitro by growing under the Aegean Region conditions. M.S. Thesis. Ege University Graduate Schoolog Natural and AppliedScience. 50 pp. Bornova, Izmir (in Turkish).

Aydemir, T., Z. Yildirim, G. Ozturk, C. Kaya. 2013. Investigation of the morphological and minituber characeristics of the land race potato populations development in vitro. 10. Field Crops Congress. 10-13 September. Konya. 675-679 pp (in Turkish).

Gunel, E. 2002. Potato cultivation from yesterday to today.III. National Potato Congress. Bornova-Izmir. 21-38 pp (in Turkish).

Kara, K. 2002. Importance and problems in term of seed potato production of Eastern Anatolia Region. III. National Potato Congress. 23-27 September. Bornova-Izmir. 53-75 pp (in Turkish)

Karaca, E. 2004. A study on the some morphological agronomical and technological traits of various potatoes collected in the Ordu area. MS.Thesis. Ondokuz Mayis University. Institute for Science (in Turkish).

Karaca, E. and S. Aytac. 2006. A study on the some phenological, morphological, agronomical and technological traits of various potatoes collected in Ordu province. IV. National Potato Congress. 6-8 September. 78-80 pp. (in Turkish)

Karadogan, T. and E. Gunel. 1992. A study on adaptation of some potato cultivars to Erzurum ecological conditions and their yield and yield components. The Journal of Agricultural Faculty of Ataturk University. 23(1): 1-5 (in Turkish)

Savkay, D. 1999. Potato called tuber vegetable. Hurriyet Newspaper, 6 February (in Turkish).

Steel, R.G.D. and J.H. Torrie. 1980. Principles and procedures of statistics. McGaw-Hill Book Company. Inc. N.Y.

Yildirim M.B. and S. Dere. 2005. Quantitative Genetics. Ege Univ. Fac. of. Agr. Dept. of field Crops. Bornova, Izmir (in Turkish)

Yilmaz, G. and Y.B. Karan. 2007. A wonderful local potato cultivar: Basciftlik beyaz1. VII. Field Crops Congress. 25-27 June. Erzurum. 728-731 pp (in Turkish). 